\title{
Analysis of the Demand Characteristics of College Students' Innovative Entrepreneurship Education
}

\author{
Qin LI ${ }^{1, a}$ \\ 1, School of Political Science and Public Administration, \\ University of Electronic Science and Technology, Chengdu, P.R. China, 611731 \\ a2256913872@qq.com
}

Keywords: Innovative Entrepreneurship Education, Demand survey, College Students

\begin{abstract}
This paper mainly analysis the characteristics of college students ' demand on innovation and entrepreneurship education with the language demand research method. First of all, we investigated the students' awareness of the school's innovative education. It shows that the students ' demand is unclear and not concentrated. Further from the curriculum design, evaluation methods, and other needs survey, Students greatly focus on the needs of multiple participation and practice. According to the survey of college students ' educational demand, it can provide reference for the development of innovation and entrepreneurship education reform in colleges and universities in the future.
\end{abstract}

\section{Introduction}

Demand-driven is relative to the ability-driven, generally speaking, the innovative entrepreneurship courses set up in colleges and universities are driven by ability, it is necessary to analyze the ability of the educated through education at the beginning of the course and training, then build the competency structure model, and design the relevant courses and training content . Then modify and perfect it, finally form the mature curriculum system. The ability-driven shows the overall demand for education. But demand-driven means that the design of educational content is determined by the needs of the educated, emphasizing that education meets the needs of individual. [1]

In recent years, innovation and entrepreneurship education in colleges and universities has been strengthened, but there are still some problems, such as "lag of educational idea" and "lack of pertinence and practicality" [2]. The main aim of the students to choose innovative Entrepreneurship course is to accomplish the credit task, and the way of acquiring knowledge is passive which is difficult for students to get real promotion and help. And for the students who really want to get promoted, the current support system does not meet the needs of their actual use. Based on this, this paper tries to study the students ' demand of innovation and entrepreneurship education, to understand the feedback and targeted demand of the existing innovative entrepreneurship education, so as to put forward the corresponding optimization suggestions to improve students ' creative ability of independent innovation.

\section{Literature Review}

\section{Needs}

Needs, also known as "demand ", is defined psychologically as "an internal tension caused by physical or mental deficiency or inadequacy, which is the reflection of the body's own or external living conditions in the brain" .The analysis in psychology is called "the sense of inadequacy and the wish of the foot". Needs activates motivation, prompting people to take some kind of action to fulfill their wants in order to achieve physical or psychological gratification [3].In this sense, it can be said that demand is the fundamental driving force of behavior.

\section{Needs Analysis}

Needs analysis, means to research the demand through various means, and has been widely used in 
education, trade, manufacturing, services and other fields. The Needs analysis mainly includes social needs and individual needs, the social needs include the needs of the government for diplomatic or other political purposes and the needs of social institutions such as companies, schools and other employers, while individual needs mainly refer to the gap between the actual level of students and their desired level [4]. In order to achieve a goal better, we need to analyze the conditions that we want to meet, clarify the specific requirements of the objectives or problems, and make feasible implementation plans. In the aspect of education and teaching, the theory of demand analysis is initially applied to the development of educational plan and curriculum, and the requirement analysis of learners is the prerequisite and foundation of a sound education plan.

\section{Analysis on the Needs of Innovative Entrepreneurship Education}

The special practical need of innovative entrepreneurship course is not only to understand what students expect to teach, but to put the whole course system within the whole innovation and entrepreneurship education support system, so as to achieve the training and promotion of innovative entrepreneurship.[5]

\section{Research and Design}

\section{Research Issues}

Through questionnaires investigates students ' evaluation of innovation and entrepreneurship education, and what kind of innovative entrepreneurship education they expected.

\section{Questionnaire Design}

In view of the lack of mature college students ' needs research for innovation and entrepreneurship, Therefore, this study intends to adopt inductive method to construct the education demand content dimension of university students' innovation and entrepreneurship, and then compile the "questionnaire on the education requirements of college students' innovation and entrepreneurship". The questionnaire was divided into two parts: basic information and formal questionnaires. The basic situation is partly composed of the students ' gender, their school, the subject and other control variables. The second part is the innovation of entrepreneurship Curriculum demand Survey, the scale of Hutchinson and water for language learners learning scale by the college students entrepreneurial Learning scale adaptation [6], the item and content statement are more in line with innovation and entrepreneurship education practice. This part is mainly used to analyze the students ' demand for innovative entrepreneurship education curriculum, from teaching organization, curriculum setting, course evaluation and other aspects to explore the needs of innovative entrepreneurship students in innovative entrepreneurship courses, a total of 15 items.

\section{Sample and Data}

The survey was conducted during the 2016 Youth competition by volunteers to send questionnaires to the participants to collect the data required, which survey of 132 participants in the 2016 youth competition and 5 universities in Sichuan Province, a total of 357 questionnaires were issued, 275 questionnaires were collected, including 265 copies of the questionnaire. From the effective questionnaires, the research has been distributed among universities, covering Tianjin University, Macau University, Jinan University, Shanghai Jiaotong University and 17 other schools. From grade one to doctoral students, of which 161 boys, 114 girls. The distribution of disciplines, including computer, communications, medicine, aviation and other science and engineering major; The sample basic information as shown in Table 1. In summary, the sample coverage of this study is more extensive, with a certain representative. 
Table1 sample statistics

\begin{tabular}{l|l|l|}
\hline \multicolumn{2}{|l}{ Sample information } & Percent (\%) \\
\hline \multirow{2}{*}{ Gender } & Male & $58 \%$ \\
\cline { 2 - 3 } & Female & $42 \%$ \\
\hline \multirow{4}{*}{ Grade } & Undergraduates & $64 \%$ \\
\cline { 2 - 3 } & Master & $29 \%$ \\
\cline { 2 - 3 } & Doctoral & $5 \%$ \\
\hline \multirow{4}{*}{ Subject background } & business & $30 \%$ \\
\cline { 2 - 3 } & science & $21 \%$ \\
\cline { 2 - 3 } & engineering & $28 \%$ \\
\cline { 2 - 3 } & arts & $19 \%$ \\
\hline \multirow{2}{*}{ Entrepreneurship Courses } & Yes & $89.10 \%$ \\
\cline { 2 - 3 } & No & $5.60 \%$ \\
\hline \multirow{2}{*}{ Entrepreneurial competition Experience } & Yes & $21 \%$ \\
\cline { 2 - 3 } & No & $21 \%$
\end{tabular}

\section{Analysis on the Demand Characteristics of Innovative Entrepreneurship Education for College Students}

\section{Overall Results and Analysis}

According to the results of the survey, in answer to the question "Do you think the education in schools meet the needs of innovation and entrepreneurship", $58.1 \%$ of the students choose to "agree with the attitude", $23.5 \%$ of the choice is "not clear", and $18.4 \%$ of the choice "generally, still need to improve." When asked about "What do you think of the school's infrastructure when it comes to innovative entrepreneurship", $76 \%$ of young people said they were good and $12 \%$ were not. As shown in Figure 1,72.8\% of the respondents studied the required courses for innovative entrepreneurship, with $82.1 \%$ of them taking elective courses.
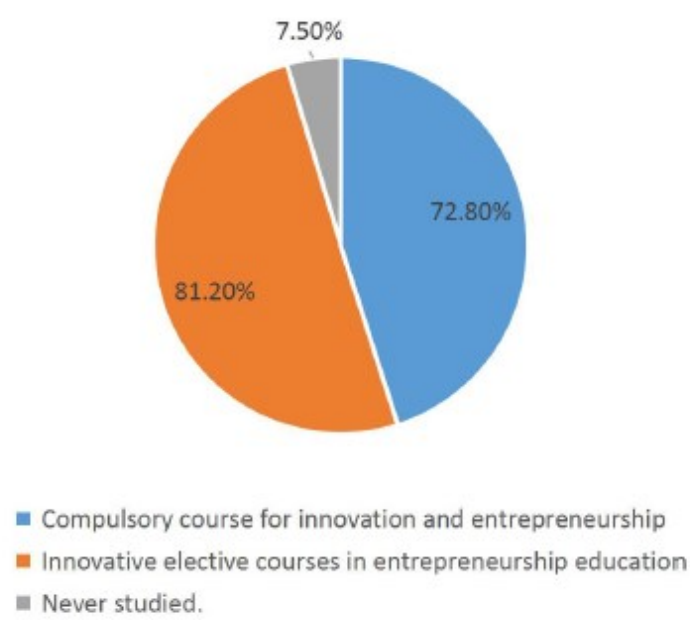

Figure 1 Learn innovative entrepreneurship courses

It can be seen that young people are more optimistic about the present university innovation and entrepreneurship education supply, the overall situation is relatively satisfactory. However, in the further investigation, there is still a situation where demand is unclear. $40.19 \%$ of the students in the school education and business needs of the docking expressed confusion, and $7.77 \%$ of the students do not know the role of the school's innovative business facilities, which indicate that the students' group has an uncertain demand for innovation and entrepreneurship education. From the survey, the "passive" input to the innovative entrepreneurial knowledge is the important reason why the demand for innovation and entrepreneurship education is unknown, and in the course study, it is only satisfied with getting the course credits. 


\section{Analysis of Curriculum Needs}

As shown in Figure 2, freshmen and sophomores are more active in taking part in the courses, while the senior students are mainly engaged in innovative and entrepreneurial activities based on projects and practices. In-depth inquiry into the students ' understanding of innovative entrepreneurship education, $15 \%$ of college students selected that innovative entrepreneurship education is course learning, $32.6 \%$ of college students selected the innovative entrepreneurship education is to listen to lectures and participate in competitions, and even $8.1 \%$ of students think that the participation in innovative entrepreneurship education is to get credits, only $44.3 \%$ of students think that innovative entrepreneurship education is to stimulate innovative entrepreneurship, to prepare for future innovation.

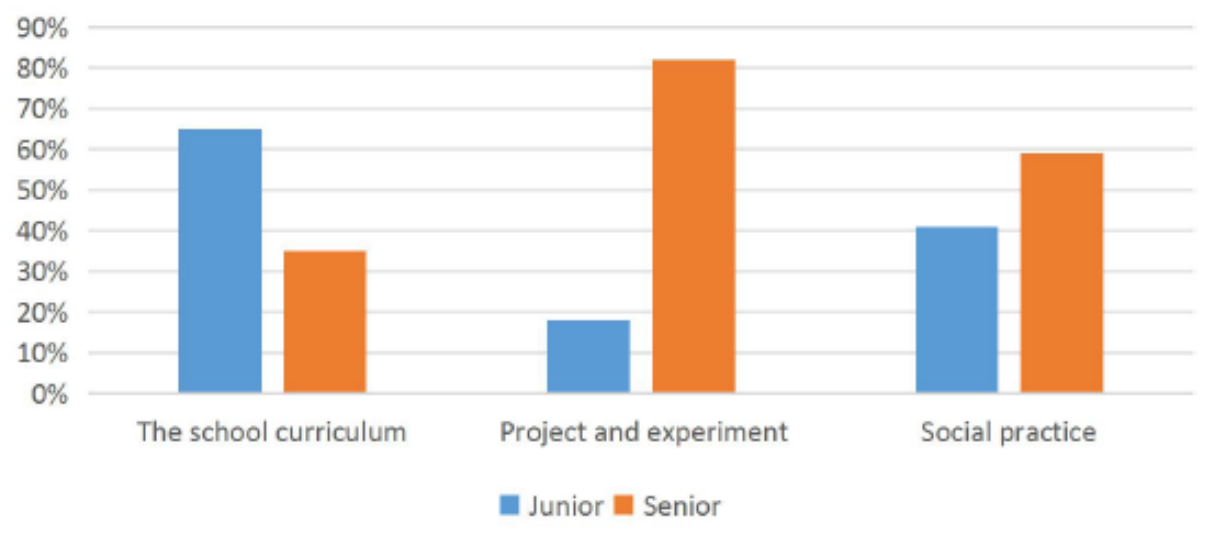

Figure 2. Curriculum needs

\section{Analysis of Education Methods}

With the rise of individualized teaching methods such as "Tutor System" and "Mooc", innovation and entrepreneurship education is no longer limited to the traditional classroom teaching, which shows the trend of diversified demand, pluralism and practice. In answer to the "most impressive way of teaching in creative entrepreneurship education in Schools", the survey results show that the students ' choice ratio is the largest in the school innovation competition and activities, accounting for $68.9 \%$, followed by "tutor one-on-one guidance" and "Open innovation entrepreneurship education courses." In addition, cooperation with other universities and enterprises has become the most attractive way to innovate entrepreneurship education.

\section{Analysis of Curriculum Evaluation Mode}

About the assessment, As shown in Figure 3, through a number of choices, 9.3\% of college students think that the school innovation and entrepreneurship Guidance course assessment should pay more attention to attendance, $21.9 \%$ of college students think should pay more attention to the publication of the paper, $48 \%$ of the university students think that should pay more attention to innovation and Entrepreneurship Competition Award, $61.3 \%$ of college students think that more attention should be paid to innovative entrepreneurial practices. In innovative entrepreneurship courses, most students want to explore their own entrepreneurial skills through specific practices and reports, and they want to learn from the experience of successful entrepreneurs. In addition, for the class teacher, $31.2 \%$ of college students believe that innovative entrepreneurship education should be provided to professional teachers in innovation, $54.7 \%$ of college students think that should be a well-known experts to provide innovative entrepreneurship education, $61.6 \%$ of college students believe that innovative entrepreneurial experience should be provided by innovative entrepreneurship Education, $12.3 \%$ of college students believe that the Department of counselors should provide innovative entrepreneurship education. 


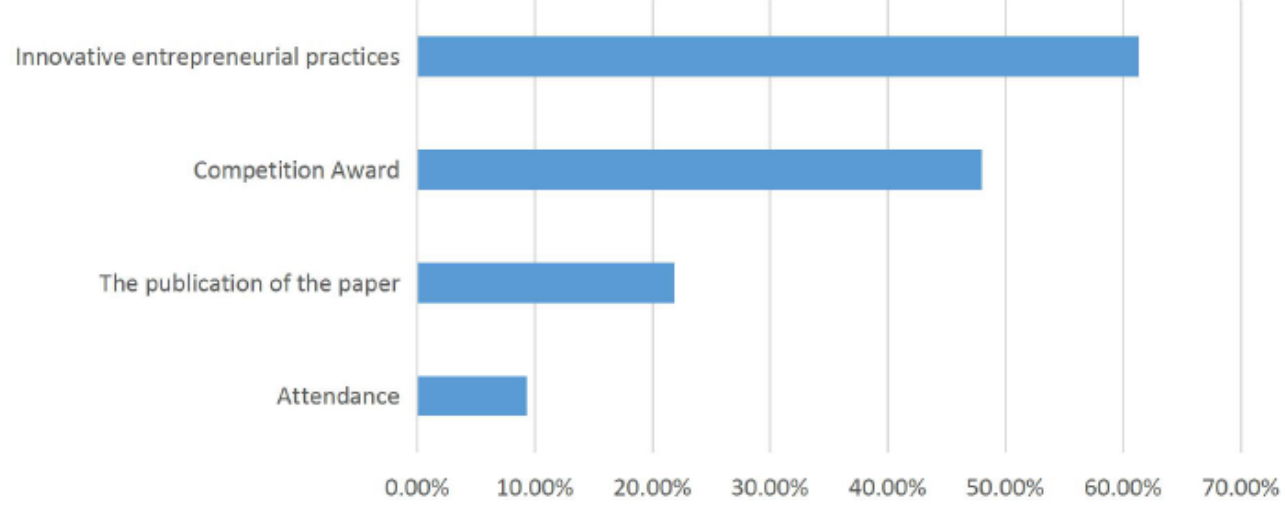

Figure 3. Curriculum evaluation mode

\section{Conclusion and Reflection}

Based on the needs of the student groups surveyed, we can get in the process of innovation and entrepreneurship education, students are uncertain or even explicitly think that the current innovation and entrepreneurship education in schools cannot meet their future demand for innovation and entrepreneurship. Innovation and entrepreneurship education needs to be presented in a clear, obvious and well-graded feature, so that students can obtain useful innovation and entrepreneurial experience before leaving the school gate.

"Because of the differences in majors, genders and part-time experiences, the specific needs of innovative entrepreneurship education will be different, which requires schools to pay full attention to the specific differences in the needs of innovative entrepreneurship education, and to implement differentiated treatment rather than simply across." "[7] For the students who are willing to do business, they will take the initiative to study and find opportunities for their own entrepreneurial needs, focusing on enterprise observation, project operation and entrepreneurship. But For students who are not willing to start a business, the main focus is to stimulating students' innovation and entrepreneurship awareness, teaching innovation and entrepreneurship knowledge, and cultivating innovative and entrepreneurial spirit.

We should perfect the curriculum system of innovation and entrepreneurship, and form a systematic and standardized training program. Through the teaching and group discussion, through the report, Business plan and practice, and so on, from point to face, from theory to practice, comprehensively cultivate students ' innovative spirit and entrepreneurial ability. And pay attention to cultivate students ' ability of exploring and cooperating, simulating the process of idea hatching and output production, encouraging students to try actively, cultivating team cooperation ability in the process of simulation, summarizing and perfecting in the process of trial and error.

The change of new economic era, the innovation of entrepreneurship education should rise to the strategic level of university, entrepreneurial courses need never become a system of sporadic characteristics of the curriculum to improve the three-dimensional innovation of entrepreneurship course system, emphasizing on the basis of innovative entrepreneurship and student-centered practice-oriented entrepreneurial teaching model.

\section{Reference}

[1]Wang zhanren, Liu Haibin, Li zhongyuan. A study on the role of creating space in innovation and entrepreneurship education in colleges and universities--on the basis of 25 field visits to 6 cities in China [j]. Ideological and theoretical education, 2016, (02): 85-91.

[2] Opinions on deepening the reform of entrepreneurship education in Institutions of higher learning [J]. Teaching of China University, 2015, (05): 4-6. 
[3]Arthur Leiber, 1985, Dictionary of Psychology [Z]. Shanghai: Shanghai Translation Publishing House, 2000.

[4][6]Chen Bingbing. Review of foreign demand analysis [j]. Foreign language teaching and Research, 2009, (02): 125-130.

[5]Liu Baocun. Establishing innovative entrepreneurship education ideas to cultivate innovative spirit and practical ability [j]. Higher education in China, 2010, (12): 12-15.

[7]Xiarenqing, Luozhimin. On the goal of entrepreneurship education under the framework of talent cultivation in colleges and universities--on the Establishment of entrepreneurship education course in colleges [j]. Fudan Education Forum, 2010, (06): 56-60. 